\title{
A Brief Overview of Sheep Husbandry in Jammu and Kashmir
}

\author{
Mubashir Ali Rather ${ }^{1 *}$, Imran Bashir ${ }^{1}$, Mohmmad Maroof Shah ${ }^{1}$, \\ Shokat Ahmad Ahanger ${ }^{1}$ and A. Hamadani ${ }^{2}$ \\ ${ }^{1}$ Department of Sheep Husbandry, Kashmir J\&K, India \\ ${ }^{2}$ Division of AGB, SKUAST-K, India \\ *Corresponding author
}

\begin{abstract}
A B S T R A C T
Livestock sector alone contributes nearly $25.8 \%$ of value of output at current prices and total value of output in agriculture, fishing and forestry sector. Livestock sector contributes $4.11 \%$ GDP and $25.6 \%$ of total Agriculture GDP. The annual contribution of livestock sector in total GDP is nearly $4.5 \%$ at current prices during 2015-16 (Anonymous, 2020). Current problems faced by livestock sector especially in a market centric economy can be better contextualized by taking a look at historical scenario. Understanding traditional basis of livestock enterprise in $\mathrm{J} \& \mathrm{~K}$ will help to evolve a counter perspective to current models that largely go unchallenged. The paper attempts to briefly document history of livestock enterprise in $\mathrm{J} \& \mathrm{~K}$ in order to show how much we have forgotten while pursuing current model of development. It attempts to also highlight difficulties faced by farmers associated with livestock sector in traditional set up and thus help us analyze current scenario. It presents facts and arguments to substantiate deep link between livestock and our agroclimatic structure and thus help to argue for reorienting our contemporary economy in their light.
\end{abstract}

\section{Keywords}

Sheep husbandry, GDP, Livestock, Agroclimatic structure

Article Info

Accepted:

15 April 2020

Available Online:

10 May 2020

\section{Introduction}

Sheep is one of the important species of livestock that contributes greatly to the agrarian economy, especially in the livelihood of a large proportion of small and marginal farmers and landless laborers. It is wellknown that the sheep rearing provides nutritional security and insurance to the farmer at the time of crisis due to crop failure. Therefore, sheep is seen as, "finance elevator" by the countryside poor farmer. Two major sources of income; meat and wool make sheep industry a very profitable enterprise. In addition, manure, a rich source of nitrogen, phosphorus and potassium is used to improve soil fertility. The UT of Jammu and Kashmir is ideally suited for rearing of sheep owing to favourable agroclimatic (temperate climate) and geo-physical conditions (presence of high mountains and low hills), rich alpine (Nai) and subalpine pastures (Nuer), meadows 
(Maedan) and host of other natural endowments. Nature has bestowed this UT with high mountains to low hills and vast meadows providing enormous scope and excellent atmosphere for sheep rearing. The pastoral areas of UT are found both in subtropical zone of Jammu Division and temperate zone of Kashmir Division. Sheep and goat rearing is the core activity of rural masses and it plays a vital role in socioeconomic upliftment of weaker sections of the society viz., Gujjars, Bakerwals, Chopans, Gaddies and Changpas. The Gujjars and Bakerwals have adopted the sheep and goat rearing as their primary occupation from times immemorial and prefer to migrate in search of pastures to feed their livestock (Anonymous, 2004). Considering the importance of this animal species, the present article is written to high light a brief historical background of sheep husbandry in J\&K.

\section{Sheep population}

Total sheep population in the country is 74.26 Million, increased by $14.13 \%$ over previous Livestock census of 2012 . The UT ranks $6^{\text {th }}$ with regard to sheep population in the country having 3.2Millionsheep and $2^{\text {rd }}$ in wool production (Anonymous, 2019). The population dynamic is presented in Table 1 and Fig 1.There are 6 native, breeds of sheep viz: Gaddi, Gurez, Bhakarwal, Poonchi, Karnah, and Changthangi (Anonymous, 2017). In addition a vast exotic repository of sheep genetic resources have been imported from different countries from time to time to improve production of mutton and wool both in terms of quality and quantity. Rambouillet and Dallen Merino were imported from USA in 1951. Merino, Corriedale. Polworth, Somalia, South Down Soviet Merino were also subsequently imported (Kaushish, 2019). Total wool production in the country is 40.42 million $\mathrm{kgs}, 2.5 \%$ decline compared to previous year. J\&K ranks $2^{\text {nd }}$ in wool production contributing $18.9 \%$ (BAHS 2019)
Man's association with animals through history

Historically animal rearing in Jammu and Kashmir is as ancient as human history. Man animal associations have continued since ages before the advent of technological revolution in the West which culminated in the development of motorized transport vehicles of various kinds (Krebs et al., 2008; Hiendleder et al., 2002). It was animals such as horses, donkeys, mules, camels, bulls and yaks etc., who provided mobility to man. In the hilly region of Jammu and Kashmir animals still, continue to be an important means of various transports in the many a treacherous terrains. The exact line of descent between domestic sheep and their wild ancestors is unclear. The most common hypothesis states that Ovis aries is descended from the Asiatic (O. orientalis) species of mouflon.

\section{History of sheep husbandry in J\&K}

Sheep rearing is not new to Jammu and Kashmir but has been practiced from times immemorial. The statement is supported by recovery of tool made from bones of domestic sheep and goat during excavation at Gufkral, Pulwama located $35.54^{\circ} \mathrm{N}$ and $75.60^{\circ} \mathrm{E}, 41$ $\mathrm{km}$ from Srinagar (Anonymous, 1984). Therefore, domestication of sheep and goat in Kashmir was practiced even before second millennium B.C. The sheep were reared in flocks $(K h u l)$ due to environmental condition, cultural habit and multitude of benefits related to sheep. Due to magnitude of benefits related its rearing a great Kashmiri saint Shaikh Noor U Din (peace be upon him) called 'sheep' is brick of gold" (Tourches onasuur). The sheep were mainly kept for mutton and wool production. The number of sheep per farmer varied according to the wealth and prosperity of owner. However, Bamzai (1984) mentioned in Socio-economic history of 
Kashmir, that the flock of five, ten, or twenty, or even more than 100 were kept by farmers.

Lawrence (1895) has mentioned in his book that ewes produced lambs twice a year i.e. during autumn and spring. However, spring born lambs were fast growing due to availability of lush green grazing. During summer, villagers were dependent on the mountain meadows and shepherd (pohol) for rearing. The renumeration was given to chaupan varied according to his reputation. Rearing was practically hereditary, and as the chaupans were a distinct class, marrying among themselves, they often protected each other from punishment or loss of clients. The shepherd was obliged to produce the head or skin (Naal) of a missing sheep or he was called upon to take an oath that the sheep was destroyed by a bear or panther or some other wild beast or any sort of disease or natural calamity, failing which, the chaupan had to return the missing sheep in the form of a sheep called Dandh. When the sheep came down from the mountain tracts were washed and thoroughly rubbed down with a hoop of iron called chelbefore sharing to harvest clean fleece clip. Three to four months later (during month of February) second clip was shorn.

The autumn clip was heavy and superior to spring clip both in terms of quality and quantity. The wool produced by sheep was having three colours: black (inferior) wool, the white (moderate), and the dark brown (superior quality). The sheep which produced dark brown were called Tooes sheep. Wool produced in the valley varied in staple length and fibre diameter. Wool obtained from Shopian area was soft compared to wool which came from around Wular lake area. The wool was known by terms moon or yaeer in Kashmir. There was also a proverb connected with wool that noon go mooni.e salt means wool, due to reason that Kashmari people believed that salt feeding increases wool yield. The important component of farmyard manure mengan (sheep droppings) of sheep was comparatively more potent than pah (cow dung). Sheep droppings were used by peasant as manure in his land. The sheep had to be confined to the sheds for a long time (Nov. to Mar.) and fed upon one's own expenses. The problem was further aggravated by the taxation policy as the sheep were heavily taxed to quote Lawrence "a tax of two annas per sheep is taken by the state". A tax of thirteen chilki was levied per hundred sheep. A tax of Zari-i-Chaupan was levied on every sheep and lamb @ 1 anna in the year 1834, but it was slightly increased at the end of the Sikh rule and the rate of tax was about Rs 8 per hundred sheep and goats. The total tax realized in $1847-48$ was Rs 42,187. During Dogra period 2 1/2annas were collected per head for sheep and goats. Since the weaker section could not afford to pay the tax thus sheep rearing became a monopoly of the rich people.

In spite of the fact villagers owned sheep, it was often difficult to obtain mutton in the villages for the people owing to their poverty. The mutton of Kashmiri sheep was considered excellent and sheep of Kashmir were considered as good as Southdown.

The climate of Kashmir Valley is temperate, the climate of Jammu and Ladakh is subtropical and arid, respectively. This variation in agroclimatic conditions along with geographical barriers has resulted in development of different and variable (in terms of production, performance and adaptation) breeds of sheep over the time. The known breeds were Bhakarwal, Changthangi, Gaddi, Gurez, Karnah, Poonchi, Malluk, Purgi etc. (Rather et al., 2019). These breeds possess unique characteristics of their own however, the poor production potential of these indigenous breeds, rising demand for apparel wool and the worldwide success of 
cross breeding, instigated authorities to adopt cross breeding programme as breeding policy.

Accordingly, the Maharaja (King) of J\&K invited Professor Alfred F. Barker of Leeds University England (1920) to suggest measures for improving the fine wool yield per animal (Anonymous, 2020). Prof. Barker visited the J\&K in 1931 (Anonymous, 2004) and after assessing geo-climatic conditions and technical feasibility, he recommended importation of specific breeds and their trials for cross breeding (Anonymous, 2020). Therefore, one Sheep Breeding Company known as Kashmir Sheep Farm Private Limited (Kashmir Sheep Farm LTD)was established (1937) with its headquarter at Banihal (Anonymous, 2020) was established. Latter, a Sheep Breeding and Research Wing was added to the company. Livestock and staff were sent to high land pastures situated at 6000-12000 ft. ASL during summer and accommodating the livestock at Reasi $2000 \mathrm{ft}$. ASL during winter. Imperial Council of Agriculture Research also sanctioned a research scheme for Banihal/Reasi farm in 1938 and six Tasmanian Merino Sheep were imported in the year 1942 for the Research Wing. The function of Kashmir Sheep Farm Pvt. Ltd. came to end in 1949 although the processes had started in 1947. During the period, Sheep Breeding Farm Goabal was also established.

In1947, the developmental activities related to sheep and goats were carried out in the State by Animal Husbandry Department. The scheme envisaged cross breeding of local sheep with Rambouillete and continued upto March 1958. After termination the ICAR scheme, the State Government decided to switch over to the Rambouillet pure breeding at the farm with a view to rapidly exploiting the achievements of cross breeding by production of large number of fine wool rams for distribution to other Government farms and among private flocks. For systematic trial and research of genetic potential, it was essential to have congenial and favorable environment. Accordingly, in 1960, Sheep Breeding and Research Farm Dachigam came into existence. Merino graded livestock was transferred from Banihal to Dachigam farm and work on development of Kashmir Merino breed was intensified. In the same year, some animals were shifted to newly established Anderwan and Billawar/Sarthal Farms and two field extension organisations were also created one at Bhaderwah in Jammu Division and the other at Beerwah in Kashmir Division. Subsequently, Wool Utilisation Research Centre at Srinagar, Fleece Testing Laboratory at Dachigam and Wool Grading and Shearing Centre at Banihal/Reasi Farm came into existence.

\section{Civil veterinary and animal husbandry department}

The Maharaja of Kashmir established a Civil Veterinary Department in 1927 with two livestock inspectors one posted in Kashmir and the other in Jammu. Veterinary services were introduced in $J \& K$ as early as first quarter of $19^{\text {th }}$ century. With advancement British influence, a royal society for prevention injuries and cruelties to animals was established. This forced administration to established treatment centres. Result, some dispensaries came into existence. During 1920-1930 there were a total of 12 dispensaries in $\mathrm{J} \& \mathrm{~K}$ of which six were named as "road dispensaries" and were located in Jhelum valley road and Banihal Cart road for the treatment of transport animals and for detection of glanders as a precautionary measure to prevent entry of the disease from Punjab. During the second decade of the 20th century, some local youth were deputed to Lahore Veterinary College to qualify as trained Vets. These people on their return were absorbed in the Department. 
Subsequently, more candidates were deputed for training to different colleges, most of them going to Lahore, Bombay and Madras Veterinary College. Simultaneously the activities in different spheres of animal health breeding and veterinary education were expanded. A foreign qualified Veterinarian (MRCVS) took over the control of the Department during 1933-34 as Superintendent Veterinary Department which was brought subordinate to the then State Development Minister directly.In the post-independence period, strong emphasis was laid on the development of Animal Husbandry, Agriculture and allied sectors to give a fillip to the economy of the peasantry. The Civil Veterinary Department got transformed into Animal Husbandry Department to ensure overall improvement in the livestock sector. (AHD)

\section{Kashmir Merino sheep breed}

Merino strain of sheep has been evolved at the Government Sheep Breeding and Research Farm, Reasi (Jammu) for the development of a new and improved breed; the Kashmir Merino in the 1960s, which is now well recognized for its fine apparel wool. This synthetic breed was developed by crossing native ewes viz; Poonchi, Gaddi and Bakerwal with Australian Merino Rams and F1 ewes so produced were bred to Delaine rams (imported from U.S.A).

Inter-se mating of F2 was done till a new breed with steady and uniform characters evolved (Anonymous, 2004). Kashmir Merino is a crossbred strain developed by crossing Gaddi, Bhakarwal and Poonchi with 50 to $75 \%$ exotic inheritance of Rambouillet and Merino sheep. Because of the involvement of a number of native and exotic breeds, the Kashmir Merino sheep are highly variable in their morphological and production performance characteristics.

\section{Creation of sheep husbandry department}

In 1962, Sheep Breeding and Development Department was carved out of Animal Husbandry Department to look after the development of sheep husbandry sector in the State and Dr. D. N. Koul (Joint Director) became the first head of the newly established Department. Dr. G.A. Bandey took over as Joint Director in October 1964 and during the next year he was elevated as the Director, J\&K Sheep Husbandry Department. Major expansion of the department took place during early seventies when two posts of Dy. Directors at provincial level were created as a1so Intensive Sheep Development Projects for migratory sheep in the zones of Reasi/Wardwan, Kathua/Bhaderwah, Padder and Srinagar/Sonmarg were formulated/implemented. Two fine wool sheep farms at Kralpathri and Daksum also came up during the same time. At Shuhama, a nucleus farm for production of mutton sheep was also established which was later on transferred to Sher-e-Kashmir University of Agriculture Sciences and Technology (SKUAST) in connection with establishment of Faculty of Veterinary Sciences and Animal Husbandry (F.V.Sc. \& A.H.). In the year 1982, the Department of Sheep Husbandry was bifurcated into two parts and accordingly one for Kashmir Division and another for Jammu Division came into existence. As a result of this bifurcation, the sheep husbandry sector got sharp focus at provincial level.

At present, the Department has two major line organizations one looking after the farms and the other field extension activities. Each organization is headed by a Joint Director. In the area of farm management, the Joint Director (Farms) is assisted by senior level officers to run the nineteen farms established so far in J\&K. Similarly, Joint Director (Extension) monitor various field programme/activities. In the migratory flocks 
of Jammu Division, the crossbred level is being maintained by Rambouillet inheritance.

The Department has established one Karakul Sheep Breeding Farm at Khumbathang (District Kargil), which was unique in the state under an Indo-U.S.S.R. protocol in the field of agriculture, the State received 60 Karakul sheep from the erstwhile U.S.S.R. consisting of 50 ewes and 10 rams for studying their performance under cold arid climatic conditions, both as pure ones and also of their crosses with native sheep. Because of strong opposition to killing of newly born lambs soon after their birth for sale of pelts, the original objective has been dropped. However, this unique breed is still maintained at the farm in view of its adoptability in cold arid desert conditions. For improvement of wool quality and production government of J\&K established many Sheep Breeding Farms presented in Table2.

Table.1 Population dynamic of sheep from 1951 to 2019

\begin{tabular}{|l|l|l|l|l|l|l|l|}
\hline Year & Sheep & Year & Sheep & Year & Sheep & Year & Sheep \\
\hline $\mathbf{1 9 5 1}$ & 9.78 & 1972 & 10.72 & 1992 & 29.47 & 2012 & 33.84 \\
\hline $\mathbf{1 9 5 6}$ & 14.65 & 1977 & 12.16 & 1997 & 31.70 & 2019 & 32.00 \\
\hline $\mathbf{1 9 6 1}$ & 11.62 & 1982 & 19.09 & 2003 & 34.14 & & \\
\hline $\mathbf{1 9 6 6}$ & 11.51 & 1987 & 12.41 & 2007 & 41.85 & & \\
\hline
\end{tabular}

Table.2 Sheep breeding farms of Jammu and Kashmir

\begin{tabular}{|l|l|c|}
\hline \multicolumn{1}{|c|}{ District } & \multicolumn{1}{|c|}{ Name of sheep Farm } & Division and Total \\
\hline District & Sheep Farm & \\
\hline Anantnag & Daksum & \\
\hline Budgam & Kralpathri & \\
\hline Baramulla & Hardshiva \\
\hline Ganderbal & Goabal & \\
\hline Srinagar & Dachigam & \\
\hline Kulgam & Kewa & \\
\hline Shopian & Zawoora & \\
\hline Kupwara & Poshnar & Ladakh (3) \\
\hline Leh & Mathoo & \\
\hline Kargil & Lakthang, Khumbathang & Jammu (6) \\
\hline Kathua & & \\
\hline Reasi $(\mathbf{2})$ & & \\
\hline Doda & & \\
\hline Poonch & & \\
\hline Ramban & & \\
\hline & Grand Total & \\
\hline
\end{tabular}


Fig.1 Population dynamics of sheep from 1951 to 2019

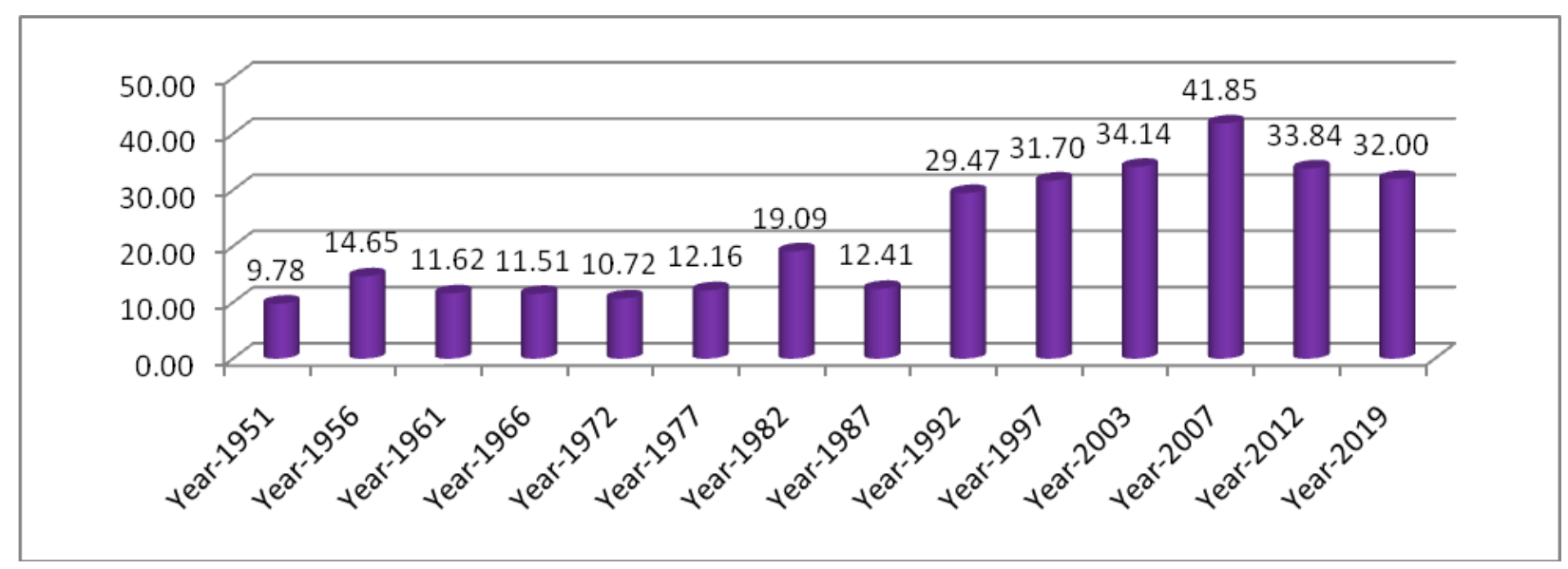

\section{Fleece testing laboratory}

For improvement in wool quality and quantity, one Fleece Testing Laboratory was established at Sheep Breeding Farm Dachigam in the year 1965. The laboratory activities are presently being carried out at Nowshera Sheep Complex. The fleece weight and its market value get largely affected by the method adopted to shear sheep. The breeders usually conduct hand shearing of their sheep twice in a year viz; spring and autumn through age-old scissors/blades. This method is highly unscientific and uneconomical as it is not only time consuming and involves more labour, but reduces the fleece weight along-with the staple length as well. Besides, it often leaves sheep with cuts and injuries. To overcome the problem, the Department introduced machine shearing of sheep in 1969 and over the years it became popular among the breeders due to its advantages over hand shearing. Besides being cost effective, the machine shearing enables the breeders to fetch better returns of their fleece by obtaining increased yield and the staple length, leaving sheep to grow another crop of good fleece by avoidance of cuts and injuries, and lastly but equally important facilitates proper grading of fleece. Petrol driven and electric shearing plants are available with the Department which are being utilized for shearing of government as well as local flocks. A nominal fee is charged from the breeders to avail the facility.

\section{Forage production wing}

Proper feeding is important for exploiting the genetic capability. The Forage Production Wing, inter-alia, aims at increasing the forage production and productivity with a view to meet the requirement of fodder for the government livestock. This is being done through introduction of high rage yielding grasses and legumes with improved management of agronomic practices. The agricultural operations are carried out on departmental land available at various farms as so in the field for production of perennial grasses and legumes like Red-Clover, WhiteClover, Tall fescue, Cox-Foot, Timothy, RyeGrass, Lucerne and other fodder crops like oats, M.P. Cheery, Cowpeas, maize and vegetables. With a view to motivating the breeders to cultivate high yielding and nutritive varieties of grasses and legumes, the Department provides them the requisite back up support terms of technical know-how and training besides free distribution of seeds, fertilizers and min kits under central assistance programme. 


\section{Employment opportunity through Sheep Husbandry}

The sheep and goat rearing provides substantial employment opportunities, as it constitutes subsidiary occupation of majority of rural masses. The potential for employment generation in sheep husbandry sector is galore by way of establishment of sheep/goat units and mini sheep farms for which the Department provides subsidy support and technical know-how as well. Sheep Husbandry Department Kashmir is in the service of sheep and goat rearers. The department welcomes any suggestion to improve the delivery system of services to make it efficient and effective. This government organization also serves to provide any information/help related to sheep and goats of Kashmir.

\section{References}

Anonymous. (1984). Indian Archaeology. (A Review), 1981-82. 19.

Anonymous. (2004). Directorate of Sheep Husbandry Kashmir division, Government of Jammu and Kashmir.

Anonymous. (2012). Government of India. $19^{\text {th }}$ All India Livestock Census. Department of animal Husbandry, Dairy \& Fisheries, Ministry of Agriculture, Government of India.

Anonymous. (2017). Livestock census report. Animal Husbandry Statistics Division, Department of Animal Husbandry, dairying and fisheries, Government of India, New Delhi.
Anonymous. (2017). National Bureau of Animal Genetic Resources. 2017. Animal Genetic Resources, Karnal. www.nbagr.res.in.

Anonymous. (2018). Directorate of Sheep Husbandry Kashmir division, Government of Jammu and Kashmir.

Anonymous. (2020). Directorate of Sheep Husbandry Kashmir division, Government of Jammu and Kashmir.

Bamzai, P.N.K. (1987). Socio-economic history of Kashmir, 1846-1925. Metropolitan Book Co. 253.

Hiendleder, S., Kaupe, B., Wassmuth, R. and Janke, A. (2002). Molecular analysis of wild and domestic sheep questions current nomenclature and provides evidence for domestication from two different subspecies. Proc. Biol. Sci., 269 (1494), 893-904.

Kaushish, S.K. (2019). Sheep Production in Tropics and Subtropics. Scientific Publishers, India

Krebs, Robert, E. and Carolyn, A. (2003). Groundbreaking Scientific Experiments, Inventions \& Discoveries of the Ancient World. Westport, CT: Greenwood Press.

Lawrence, W.R., 1895. The valley of Kashmir. Nabu Press, India

Rather, M., Shanaz, S., Ganai, N.A., Bukhari, S., Hamadani, A., Nabi, N.N., Yousuf S, Baba A. and Raja T. (2019). District wise location of Sheep Breeding Farms: evaluation of wool traits of Kashmir Merino sheep in organized farms. Small Ruminant Research, 177(6), 14-17.

\section{How to cite this article:}

Mubashir Ali Rather, Imran Bashir, Mohmmad Maroof Shah, Shokat Ahmad Ahanger and Hamadani, A. 2020. A Brief Overview of Sheep Husbandry in Jammu and Kashmir. Int.J.Curr.Microbiol.App.Sci. 9(05): 1644-1651. doi: https://doi.org/10.20546/ijcmas.2020.905.185 